\title{
Effect of sildenafil citrate on the liver structure and function in obstructive jaundice: An experimental study
}

Tamer Șimșek, Ömer Faik Ersoy, Zeki Özsoy (D), Erdinç Yenidoğan, Hüseyin Ayhan Kayaoğlu, Namık Özkan, Mustafa Șahin

ABSTRACT Objective: We aimed to investigate the effect of $10 \mathrm{mg} / \mathrm{kg}$ sildenafil on the structure and function of the liver in a rat model of obstructive jaundice.

Material and Methods: Sixty-two male Wistar albino rats were distributed into six different groups. Obstructive jaundice was performed by legating the common bile duct. $10 \mathrm{mg} / \mathrm{kg}$ sildenafil citrate in drinking water was delivered orally after the operation before sacrificing them. Rats were sacrificed either after 10 or 28 days according to the study design. The blood and tissue samples from the liver were obtained to perform a biochemical and histopathological analysis to study functional and structural changes in the liver.

Results: At the 10th day, there was no difference between the sildenafil-treated and control groups with regard to the aspartate aminotransferase and alanine aminotransferase levels $(p=0.423, p=0.661)$. The alkaline phosphatase total bilirubin levels among the groups were statistically different $(p<0.001)$. At the 28th day, liver function tests except alanine aminotransferase showed significant differences among the groups $(p<0.001)$. Liver function tests did not changed significantly between the 10th and 28 th day in sildenafil-treated rats $(p>0.05)$. Significant differences were observed among the groups with regard to cholestasis, fibrosis, inflammation, and necrosis $(p<0.001)$. However, edema increased in the sildenafil-treated group $(p<0.001)$. On the 28 th day, the severity of structural changes in the liver after obstructive jaundice, except edema, reduced significantly $(p<0.001)$. The sildenafil-treated groups at different time points didn't show any statistical difference in histopathological changes $(p>0.05)$.

Conclusion: Oral administration of $10 \mathrm{mg} / \mathrm{kg}$ sildenafil citrate dramatically reverses the biochemical and histopathological liver changes induced by obstructive jaundice in rats.

Keywords: Sildenafil citrate, liver, obstructive jaundice, rats

ORCID ID of the corresponding author: Z.0. 0000-0003-1305-5767

Cite this paper as: Şimşek T, Ersoy ÖF, Özsoy Z, Yenidoğan E, Kayaoğlu HA, Özkan N, et al. Effect of sildenafil citrate on the liver structure and function in obstructive jaundice: An experimental study. Turk J Surg 2018; 34: 111-116.

Department of General Surgery, Gaziosmanpaşa University School of Medicine, Tokat, Turkey This study was presented at the "XVI. Annual Meeting of the European Society", 22-24 November, 2012, İstanbul, Turkey.

\section{Corresponding Author} Zeki Özsoy

e-mail:zekiserkanozsoy@

hotmail.com

Received: 21.11.2016

Accepted: 18.05.2017

CCopyright 2018

by Turkish Surgical Association

Available online at

www.turkjsurg.com

\section{INTRODUCTION}

Obstructive jaundice develops as a result of a bile obstruction in the intrahepatic and/or extrahepatic biliary tract. The obstruction occurs somewhere between the bile production in the liver and its secretion in the gastrointestinal system (1). Depending on the etiology, an obstruction might be partial, or in some cases, a complete obstruction can occur. Clinical findings occurring with obstructive jaundice may be reversible with an early diagnosis and therapy when the cause of obstruction is removed. However, in some cases, when the cause of obstruction cannot be removed, or when the obstruction takes a longer time to clear, permanent functional and histopathologic changes can occur. The functional and structural changes that occur in the liver as a consequence of obstructive jaundice could return to normal after only days or weeks following an internal or external drainage process (2). For this reason, to minimize the development of liver injury in obstructive jaundice, several agents and methods have been and are still being investigated (3-7).

Phosphodiesterase-5 (PDE-5) enzyme inhibitors have different impacts on hemodynamic parameters in the liver (8). Sildenafil citrate is also a PDE-5 inhibitor and is often used for erectile dysfunction (8). Sildenafil causes the c-GMP levels to increase by inactivating PDEs that metabolize c-GMP. Furthermore, cGMP is an intracellular mediator of the nitric oxide (NO) pathway and causes an increase in NO synthesis. NO causes relaxation of the vascular smooth muscle structure, vasodilatation, increases in blood flow, inhibition of platelet aggregation, and inhibition of both platelet aggregation and microcirculation (9). Under physiological conditions, NO plays an important role in the liver's microvascular blood flow (10).

In this study, we aimed to investigate the impacts of daily oral sildenafil ( $10 \mathrm{mg} / \mathrm{kg}$ ) on functional and structural liver changes at 10 and 28 days of an experimental obstructive jaundice model in rats.

\section{MATERIAL AND METHODS}

\section{Procedure and Evaluation}

This study was approved by the Ethics Committee of Gaziosmanpasa University Medical Faculty. Rats were obtained from the Gaziosmanpasa University Experimental Research Center. All animals received humane care in accordance with local laboratory animal research regulations. Sixty-two male Wistar albino rats, weigh- 
ing 250 to $300 \mathrm{~g}$, were randomly allocated into six groups (Sham 10; Sham 28; Control 10; Control 28; Sildenafil 10; and Sildenafil 28). All operative processes and follow-up treatments were held at Gaziosmanpasa University Animal Studies Research Center. Rats were housed in wire cages with free access to food and water under standard laboratory conditions (room temperature: $23^{\circ} \mathrm{C}$; 12-hour light-dark cycles). They were not fed for 12 hours before the operation, but they had free access to water.

\section{Surgery and Experimental Protocol}

Before the operative process, anesthesia was induced by an intraperitoneal injection of ketamine hydrochloride $(75 \mathrm{mg} /$ kg; Ketalar, 500 mg flacon; Pfizer, Istanbul, Turkey) and xylazine hydrochloride (10 mg/kg; Rompun 2\% flacon; Bayer, Istanbul, Turkey). After skin preparation, a midline laparotomy of $2-3 \mathrm{~cm}$ was made. The duodenum was found by following the stomach and pylorus. Through a slightly forward and downward traction of the duodenum, the common bile duct extending from the liver hilum to the duodenum was seen. Holding the fatty tissue with a thin hemostat, the common bile duct was released (11).

Group 1 (Sham 10): The rats in this group underwent only the common bile duct exploration, and then the process was ended. The rats were sacrificed on the $10^{\text {th }}$ day.

Group 2 (Sham 28): The rats in this group underwent only the common bile duct exploration, and then the process was ended. The rats were sacrificed on the $28^{\text {th }}$ day.

Group 3 (Control 10): The rats in this group underwent a mechanical obstructive jaundice model, and then the process was ended. The rats were sacrificed on the $10^{\text {th }}$ day.

Group 4 (Control 28): The rats in this group underwent a mechanical obstructive jaundice model, and then the process was ended. The rats were sacrificed on the $28^{\text {th }}$ day.

Group 5 (Sildenafil 10): The rats in this group underwent a mechanical obstructive jaundice model, and then the process was ended. After the procedure, $10 \mathrm{mg} / \mathrm{kg} /$ day of sildenafil was given orally until the time of sacrifice. The rats were sacrificed on the $10^{\text {th }}$ day.

Group 6 (Sildenafil 28): The rats in this group underwent a mechanical obstructive jaundice model, and then the process was ended. After the procedure, $10 \mathrm{mg} / \mathrm{kg} /$ day of sildenafil was given orally until the time of sacrifice. The rats were sacrificed on the $28^{\text {th }}$ day.

Experimental obstructive jaundice was induced by a knot tied on the common bile duct with 4/0 silk sutures and transected so as to prevent recanalization. The fascia and skin were closed by 4/0 monofilament polypropylene (Prolene, Ethicon) running sutures. All animals were resuscitated by a subcutaneous injection of saline $(8-10 \mathrm{~mL} / \mathrm{kg})$ to the dorsal area.

\section{Drug Application}

The drug was completely crushed and mixed with $2-3 \mathrm{ml}$ of drinking water. Then it was thoroughly mixed until it became a homogenous suspension. Using a gavage injector, the solution was completely administered orally. Starting from the day
(Vıagra, Pfizer; Istanbul, Turkey) was given in a $10 \mathrm{mg} / \mathrm{kg}$ dose by gavage every day at the same hour.

\section{Sacrifice and Collecting the Blood and Tissue Samples}

The rats in the sham, control, and sildenafil group were sacrificed on the $10^{\text {th }}$ (Sham 10, Control 10 and Sildenafil 10) or $28^{\text {th }}$ day (Sham 28, Control 28 and Sildenafil 28) according to the study design. The blood and tissue samples were collected for biochemical analysis of liver functions and for histopathological evaluation of liver structural changes. Sacrifice was performed in accordance with laboratory conditions. Before the procedure, the rats were anesthetized with $30 \mathrm{mg} / \mathrm{kg}$ hydrochloride and $5 \mathrm{mg} / \mathrm{kg}$ xylazine. After the intracardiac blood sampling, a laparotomy through the previous incision was made, and a total hepatectomy was performed.

\section{Biochemical Analyses of Liver Functions}

The blood samples were centrifuged for 5 minutes at 2,000 rpm, and the plasma was separated. Aspartate aminotransferase (AST; U/L), alanine aminotransferase (ALT; U/L), alkaline phosphatase (ALP; U/L) and total and direct bilirubin (TBIL and DBIL, respectively; $\mathrm{mg} / \mathrm{dl}$ ) levels were measured with the enzyme-linked immunosorbent assay.

\section{Histopathological Evaluation of Liver Structural Changes}

The histological evaluations of the specimens were performed by the same blinded pathologist. The hepatic tissue specimens were fixed in $10 \%$ neutral-buffered formalin, embedded in paraffin, sectioned at $5 \mu \mathrm{m}$, and stained with hematoxylin and eosin for histopathological evaluation. Histopathological examinations of the prepared samples were done by light microscopy. In the examination of the liver tissue samples, ductal proliferation, periductal edema, cholestasis, portal and periductal inflammation, and the presence of necrosis were examined. The extent of histopathological changes in the liver tissue was graded by using a 4-point scoring system ( 0 , none; 1, mild; 2, moderate; and 3, severe).

\section{Statistical Analysis}

All data are presented as the mean \pm standard deviation. Statistical analyses were performed using the Statistical Package for Social Sciences (SPSS) version 13.0 (SPSS Inc.; Chicago, IL, USA). Statistical evaluation of numeric variables was performed by a one-way analysis of variance, followed by a Tukey's post hoc test. Non-numeric variables were evaluated with the $x^{2}$ test. A $p$ value of less than 0.05 was considered statistically significant.

\section{RESULTS}

No intraoperative or postoperative deaths occurred in the rats. We also did not observe any infective complications in either the control or experimental groups during the followup period.

\section{Biochemical Measurements}

Liver function tests after 10 and 28 days showed a significant difference between the sham group and other groups $(p<0.001)$. Although there was a decrease in the AST, ALT, and DBIL levels of the groups treated with sildenafil when compared to the control groups, this difference was not statistically significant. For the ALP and TBIL levels, a significant difference was seen among all groups $(p<0.001)$ (Figure 1$)$. On the $28^{\text {th }}$ day, there were significant differences in the AST, ALP, TBIL, and DBIL measurements between the sildenafil group and the 

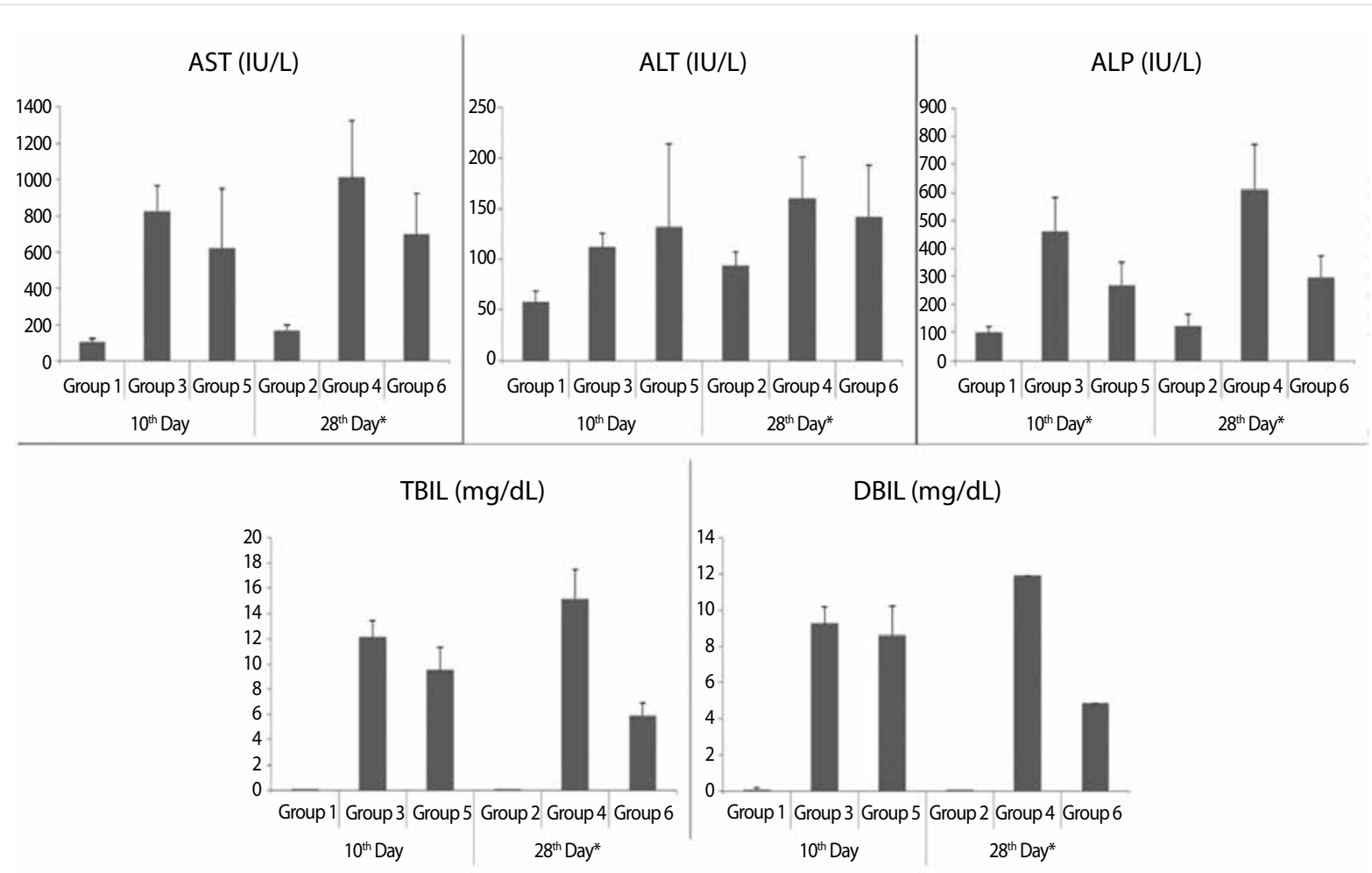

Figure 1. Results of Liver Function Tests

AST: aspartate aminotransferase; ALT: alanine aminotransferase; ALP: alkaline phosphatase; TBIL: total bilirubin; DBIL: direct bilirubin * Statistically significant $(p<0.001)$

control group $(p<0.001)$. A decrease was also seen in ALT levels, but this was not significant $(p=0.1)$ (Figure 1$)$. On the $10^{\text {th }}$ and $28^{\text {th }}$ days, when the sildenafil groups were compared between each other in terms of liver function tests, no significant difference was seen $(p>0.05)$.

\section{Histopathological Evaluations}

On the $10^{\text {th }}$ and $28^{\text {th }}$ days, a significant difference arising from the sham group was seen with regard to ductal proliferation $(p<0.001)$. However, there was no significant difference between the control group and sildenafil group ( $p>0.05$ ). On the $10^{\text {th }}$ and $28^{\text {th }}$ days, a significant difference regarding cholestasis, fibrosis, edema, inflammation, and necrosis were detected in all groups $(\mathrm{p}<0.001)$. In the sildenafil group, a significant decrease in cholestasis, fibrosis, inflammation, and necrosis levels were noticed $(p<0.001)$. In this group, edema increased on the $10^{\text {th }}$ day $(p<0.001)$ and remained the same on the $28^{\text {th }}$ day $(p=0.112)$. On the $10^{\text {th }}$ and $28^{\text {th }}$ days, no significant differences were seen in terms of histopathological changes when the sildenafil groups were compared with each other $(p>0.05)$. However, although there was no significant difference, an increase in the level of ductal proliferation, fibrosis, and necrosis, and a decrease in edema and inflammation were observed on the $28^{\text {th }}$ day. There was no change in cholestasis levels. Histopathological changes in the liver induced by sildenafil citrate in rats are presented in Figure 2.

\section{DISCUSSION}

Obstructive jaundice is an area intensively studied both experimentally and clinically. However, despite new improvements in its treatment, it is still one of the most important surgical problems. Endotoxemia has a significant role in the patho- physiological changes that occur (12). Two factors are responsible for endotoxemia development. The first is the absence of an anti-endotoxin effect provided by bile salts in the digestive tract, and the absorption of endotoxins into the portal circulation. The second is the escape of endotoxins arising from the bowels into the systemic circulation due to the impairment of phagocytic functions of the hepatic Kupffer cells $(13,14)$. Emerging systemic endotoxemia activates an inflammatory response causing organ functions to deteriorate. Related to these changes, a clinical picture might develop with severe morbidity and mortality, and it may include conditions such as acute respiratory distress syndrome, renal failure, hepatorenal syndrome, several cardiovascular problems, and multiple organ failure (15). Thus, for these reasons, obstructive jaundice is extensively studied both experimentally and clinically. While in hepatocellular damage the increase in AST is more prominent, in obstructive jaundice, the increases in ALP, TBIL, and DBIL are at the forefront (16). In our study, the highest levels among the control groups in terms of liver function tests were observed remarkably on the $28^{\text {th }}$ day. The reason for this is due to the damage of prolonged biliary retention on liver cells (17). In our study, the decrease in ALP and TBIL levels in liver function tests were significant in the group treated with sildenafil for 10 days. On the 28th day, a decrease in all liver function tests, except for ALT, was seen in all the sildenafil groups. This result shows that the long-term use of sildenafil is effective in recovery of liver function tests that decreased due to obstructive jaundice.

In obstructive jaundice, an increase in the biliary pressure due to the accumulation of bile salts occurs in the common bile duct. During the first week of the obstruction, edema, neutro- 


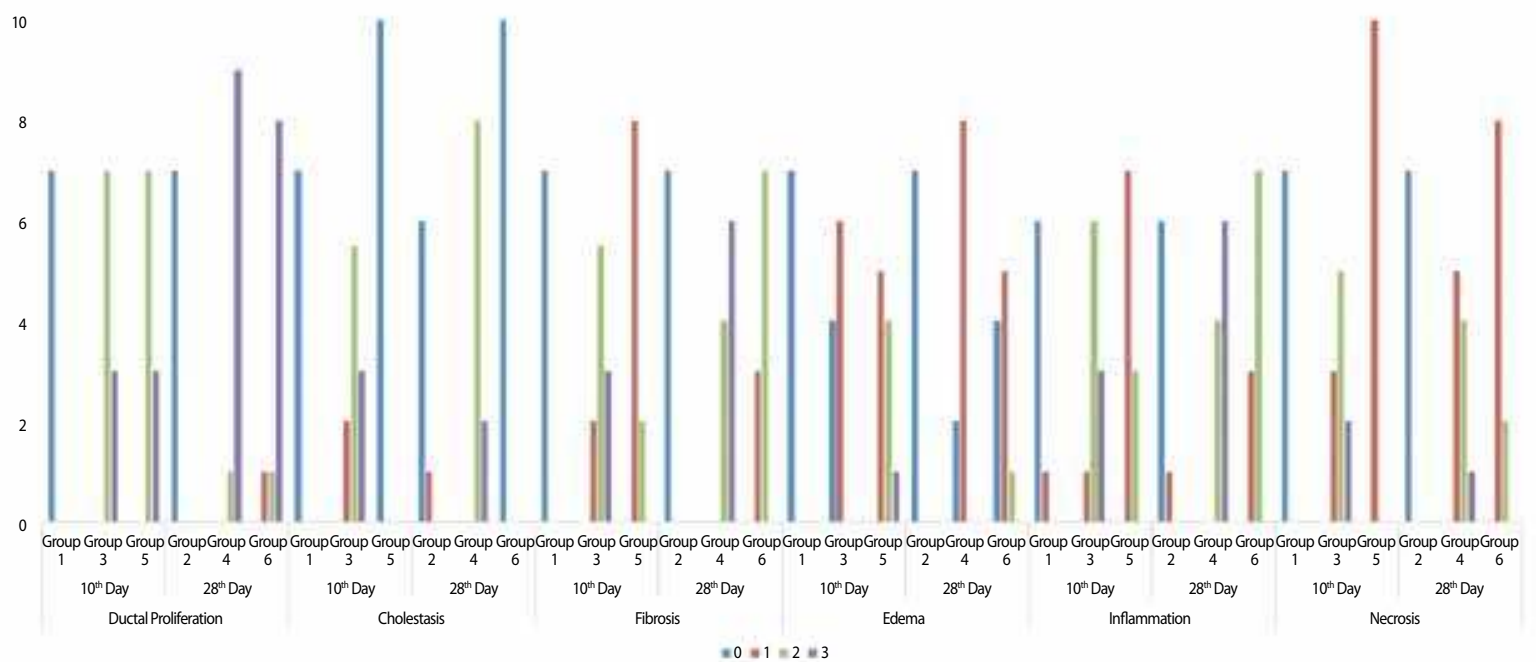

Figure 2. Histopathological Changes in the Liver Induced by Sildenafil Citrate in Rats

In the examination of liver tissue samples, ductal proliferation, periductal edema, cholestasis, portal and periductal inflammation, and the presence of necrosis were examined. The extent of histopathological changes in the liver tissue was graded by using a 4 point scoring system ( 0 , none; 1 , mild; 2 , moderate; and 3, severe)

Significant differences were observed among the groups with regard to cholestasis, fibrosis, inflammation, and necrosis $(p<0.001)$. However, edema increased in the sildenafil-treated group $(p<0.001)$. At the 28th day, the severity of structural changes in the liver after obstructive jaundice, except edema, was reduced significantly $(p<0.001)$

phils, and lymphocytes might be seen in the portal area. Along with portal inflammation, bile duct proliferation is observed in the periportal area. If the obstruction continues, fibrosis and fibrous septa are noticed along periportal and periseptal areas, which are indicators of chronic cholestasis. Related to the increased collagen content, hepatic stricture occurs. The regenerative ability of the liver decreases, and fibrogenic activity increases. Fibrosis then replaces the normal liver structure. The causes of bile infarcts developed during the late period include a duct damage related to increased biliary pressure, the direct impact of bile components on hepatocytes, and the indirect impacts of bilirubin and bile acids in the blood. As the infarct develops, fibrotic and necrotic areas increase, and the tissue damage becomes permanent. Morphological changes continuing in the liver result in the occurrence of secondary biliary cirrhosis and regeneration nodules after months (17). In electron microscopic studies of the obstructive jaundice model, hepatocytes were observed to lose their secretory functions. It was found that mitochondria swelled, and serious deformities occurred. Additionally, due to the decrease in protein synthesis, gluconeogenesis and ketogenesis disorders of mitochondrial activity were found $(18,19)$. In our study, we found a significant decrease in many of the negative effects of delayed bile emptying in the early (10th day) and late (28th day) periods on liver tissue in the obstructive jaundiced rats treated with sildenafil. For instance, decreases in cholestasis, fibrosis, inflammation, and necrosis were observed in both time periods; however, edema was increased only in the early period.

The vasodilatation effect of sildenafil and PDE-5 inhibitors causes the activation of kinases through the release of endogenic mediators such as bradykinin and/or adenosine and subsequent NO synthesis. NO forms c-GMP by activating guanylate cyclase. C-GMP opens mitochondrial K-ATP channels by protein kinase G (PKG) activation. It is thought that, in cases when intracellular $\mathrm{pH}$ and ATP synthesis decrease, as with ischemia-reperfusion, the opening of these channels reactivates metabolic functions by stabilizing the intracellular acidic environment, and therefore, it might be effective in preventing damage. K-ATP channels are found not only in the heart, but also in all endothelial cells of the body.

NO exerts a positive impact on several stages of wound recovery due to its effects on angiogenesis and inflammation in the endothelium and epithelium. Kim et al. (20) showed that necrosis developing in ischemia-reperfusion damage of NO can be prevented by c-GMP and the guanylate cyclasedependent kinase pathway. Gursoy et al. (21) researched the impact of sildenafil on wound recovery and showed that sildenafil makes a positive contribution by increasing the neovascularization and abdominal wall tensile force. Cakir et al. (22) stated that sildenafil had a histopathologically positive impact on colon anastomosis recovery. Sarifakioglu et al. (23) examined the effect of sildenafil citrate on the flap life and showed that it increased the length of flap life, a property they suggest comes from two sildenafil features. These features include the promotion of increased vasodilation and the prevention of potential vascular thromboses by affecting thrombosis aggregation. Tas et al. (24) showed that sildenafil increased new capillary formation as well as vasodilatation. Furthermore, Irkorucu et al. (25) found that sildenafil causes a decrease in mucosal damage.

As for the liver, sildenafil decreases vascular resistance by increasing the NO release and decreasing the portal pressure $(26,27)$. Colle et al. $(28)$ examined the impact of sildenafil on rats with experimentally induced cirrhosis. They founded that intramesenteric and intravenous injections of sildenafil decreased the mean arterial blood pressure and increased the 
mesenteric blood flow and portal venous pressure, depending on the dosage. In a different study, it was stated that no significant increase was observed in superior mesenteric artery blood flow in an experimental obstructive jaundice model when NO synthesis was prevented; subsequently, no significant recovery occurred in either liver functions or tissue histopathological changes (29). Li et al. (30) examined the impact of sildenafil in experimental liver damage in rats. They found that liver hypoxia and liver damage decreased due to the increase in smooth muscle relaxation caused by increased NO levels generated by sildenafil. At the end of this study, they concluded that sildenafil might prevent damage in post-ischemia hepatocytes by regulating oxygen consumption.

Although it is rare according to literature, in some studies, hepatotoxicity is reported to be caused by sildenafil. The sildenafil citrate was investigated in a study published in 2011, in terms of its histological effects on adult Wistar rats that were treated with sildenafil every day, for a period of 6 weeks (31). Regarding the histological results, the study reported a dilatation of the central vein of the liver with lysed red blood cells and a cytoarchitectural distortion of the organ. Increased levels of liver enzymes were also noted. It was suggested that a probable toxic effect of sildenafil might have affected the hematopoietic function of the liver to a great extent. The study conducted by Nna et al. (32) reports that as it is indicated in the increased serum concentration of liver enzymes and bilirubin, significant alteration in liver functions could occur following the chronic administration of sildenafil in adult Wistar rats; and only a poor reversal of hepatotoxicity was observed after the withdrawal of the sildenafil. Jarrar and Almansour. (33) reported that significant biochemical and structural alterations in the hepatic tissue that have potential effects on liver functions were observed as a result of subchronic exposure to sildenafil overdoses (e.g., hepatocytes nuclear alterations, necrosis, bile duct hyperplasia, inflammatory cells infiltration, hepatic vessels congestion). Even though a possible link between hepatotoxicity and the use of sildenafil is indicated in the related literature, the mechanism underlying liver toxicity still remains unknown. However, it should be considered that the manifestations of drug-induced hepatotoxicity are highly variable, ranging from asymptomatic elevation of liver enzymes to fulminant hepatic failure, and so it could be possible that some sildenafil-associated hepatotoxicity cases may have been totally missed, especially when sildenafil consumption is not declared, illicit, and/or unaware (i.e., in case of counterfeit herbal products for erectile dysfunction) (34-37). Normality values were noted in clinical condition and liver enzymes within 20 days after the withdrawal of sildenafil, which indicates a diagnosis of sildenafil-associated hepatotoxicity from unknown mechanisms (34).

There are some limitations to this study. First, based on the molecular mechanisms mentioned before, an increased NO synthesis might have led to the positive biochemical and histopathological effect of sildenafil on hepatocytes in obstructive jaundice in this study. However, this study did not research this issue. Second, obstructive jaundice has been reported to cause significant oxidative stress and inflammatory reaction in the liver. Although this study showed that inflammation, necrosis, and fibrosis reduced with treatment, its antioxidative effect was not assessed.

\section{CONCLUSION}

This study showed that the use of $10 \mathrm{mg} / \mathrm{kg}$ of sildenafil by an oral route for 10 and 28 days in an experimental obstructive jaundice model might amend the functional and structural liver changes occurring during biliary obstruction. In this model, the inflammation, necrosis, and fibrosis observed in the liver tissue during prolonged jaundice decreased significantly with sildenafil. We think that the effect of sildenafil on obstructive jaundice should be investigated in more detail both at the molecular level and with regard to its clinical use.

Ethics Committee Approval: Ethics committee approval was received for this study from the ethics committee of Gaziosmanpaşa University School of Medicine.

Informed Consent: Not required in this study.

Peer-review: Externally peer-reviewed.

Author Contributions: Concept - T.S., O.F.E., N.O.; Design - T.S., O.F.E., Z.O., N.O.; Supervision - E.T., H.A.K.; Resource - T.S., O.F.E.; Materials - T.S., O.F.E., N.O., Z.O.; Data Collection and/or Processing - T.S., O.F.E., Z.O.; Analysis and/or Interpretation - T.S., O.F.E., Z.O.; Literature Search - T.S., Z.O.; Writing Manuscript - T.S., O.F.E., Z.O., E.Y.; Critical Reviews - Z.O., H.A.K.

Conflict of Interest: The authors have no conflicts of interest to declare.

Financial Disclosure: The authors declared that this study has received no financial support.

\section{REFERENCES}

1. Gümüs $M$, Tekin R, Firat $U$, Onder $A$, Kapan $M$, Böyük $A$, et al. The effects of pomegranate on bacterial translocation in rats with obstructive jaundice. Eur Rev Med Pharmacol Sci 2013; 17: 14881494.

2. James S Doley. Extrahepatic biliary obstruction. Systemic effects, diagnosis,management. In: Bircher J, Benhamou J-P (Eds). Oxford Textbook of Clinical Hepatology (2th ed) Oxford: 1999; pp 15811590.

3. Mersin HH, Akbaba M, Başkan E, Berberoğlu U. N-acetylcysteine can attenuate liver injury in obstructive jaundice in rats. Turk $J$ Surj 2009; 1: 146-149.

4. Doğan U, Karabulut Z, Hamamcı O, Sökmensüer C, Ercis S, Korkmaz A. N-asetilsistein'in tıkanma sarılığında bakteriyel translokasyona, karaciğer ve ileumdaki yapısal değişikliklere etkisi. Turk J Surj 2005; 21: 15-20.

5. Cantürk NZ, Canturk Z, Utkan NZ, Yenisey C, Ozbilim G, Yildirir $C$, et al. Cytoprotective effects of alpha tocopherol against liver injury induced by extrahepatic biliary obstruction East Afr Med J 1998; 75: 77-80.

6. Doğan U, Korkmaz A, Erciş S, Doğan H. Tıkanma sarılığı modelinde büyüme hormonunun bakteriyel translokasyona ve karaciğer ile ince barsaktaki yapısal histopatolojik değişiklikler üzerine etkisi. Turk J Surg 2007; 23: 112-116.

7. Onalan AK, Tuncal S, Kilicoglu S, Celepli S, Durak E, Kilicoglu B, et al. Effect of silymarin on oxidative stress and liver histopathology in experimental obstructive jaundice model Acta Cir Bras 2016; 31: 801-806. [CrossRef]

8. Halverscheid L, Deibert P, Schmidt R, Blum HE, Dunkern T, Pannen $\mathrm{BH}$, et al. Phosphodiesterase- 5 inhibitors have distinct effects on the hemodynamics of the liver. BMC Gastroenterol 2009; 18; 9:69.

9. Tang WH, Zhuang XJ, Ma LL, Hong K, Zhao LM, Liu DF, et al. Effect of sildenafil on erectile dysfunction and improvement in the quality of sexual life in China: a multi-center study. Int J Clin Exp Med 2015; 15; 8: 11539-11543. 
10. Baveja R, Keller S, Yokoyama Y, Sonin N, Clemens MG, Zhang JX. LPS-induced imbalanced expression of hepatic vascular stress genes in cirrhosis: possible mechanism of increased susceptibility to endotoxemia. Shock 2002; 17: 316-321 [CrossRef]

11. Kesici H, Ulusoy AN, Topgül K, Paşaoğlu H, Bayraktar N, Şenyürek $\mathrm{G}$, et al. Tıkanma sarılıklı ratlarda taurolidine'in kolonik anastomoz iyileşmesi üzerine etkisi. Turk J Surg 2007; 23: 001-009.

12. Akca T, Canbaz H, Tataroglu C, Caglikulekci M, Tamer L, Colak T, et al. The effect of $\mathrm{N}$-acetylcysteine on pulmonary lipid peroxidation and tissue damage. J Surg Res 2005; 129: 38-45. [CrossRef]

13. Aldemir $M$, Geyik $M$, Kökoğlu $O$, Büyükbayram $H$, Hoşoğlu $S$, Yağmur Y. Effects of ursodeoxycholic acid, glutamine and polyclonal immunoglobulins on bacterial translocation in common bile duct ligated rats. ANZ J Surg 2003; 73: 722-726. [CrossRef]

14. Sheen-Chen $S$, Chau P, Haris W. Obstructive jaundice alters kuppfer cell function independent of bacterial translocation. J Surg Res 1998; 80: 205-209. [CrossRef]

15. Onder A, Kapan M, Yuksel H, Tekin R, Kele A, Evliyaoglu O, et al. The effects of erythropoietin on bacterial translocation and inflammation in rats with obstructive jaundice. Ann Ital Chir 2014; 85: 159-165.

16. Moss DW, Henderson AR. Clinical Enzymology. In: Burtis CA, Ashwood ER, eds. Tietz textbook of Clinical Chemistry. Philadelphia, Pennsylvania: W.B. Saunders Company, 1999: 652-654.

17. Kumar, V, Abbas, A K, Fausto N, \& Aster, J C. Robbins Pathologic Basis Disease (6th ed). WB Saunders Company, Philadelphia 1999; 100-101.

18. Aykaç G, Özdemirler G, Alptekin N, Arican N, Oz B, Uysal M, et al. The hepatic lipid peroxidation, copper and fibrosis in cholestatic rats. Pharmacol Res 1989; 21: 701-706. [CrossRef]

19. Rege RV. Adverse effect of biliary obstruction: Implication for treatment of patients with obstructive jaundice. AJR Am J Roentgenol 1995; 164: 287-293. [CrossRef]

20. Kim JS, Ohshima S, Pediaditakis P, Lemasters JJ. Nitric oxide protects rat hepatocytes against reperfusion injury mediated by the mitochondrial permeability transition. Hepatology 2004; 39: 1533-1543. [CrossRef]

21. Gürsoy K, Oruç M, Kankaya Y, Ulusoy MG, Koçer U, Kankaya D, et al. Effect of topically applied sildenafil citrate on wound healing: experimental study. Bosn J Basic Med Sci 2014; 16; 14: 125131. [CrossRef]

22. Cakir T, Ozer I, Bostanci EB, Keklik TT, Ercin U, Bilgihan A, et al. Increased collagen maturity with sildenafil citrate: experimental high risk colonic anastomosis model. Int J Surg 2015; 13: 152156. [CrossRef]

23. Sarifakioglu N, Gokrem S, Ates L, Akbuga UB, Aslan G. The influence of sildenafil on random skin flap survival in rats: an experimental study. Br J Plast Surg 2004; 57: 769-772. [CrossRef]
24. Tas A, Atasoy N, Ozbek H, Aslan L, Yüksel H, Ceylan E, et al. The effects of sildenafil citrate (Viagra) in the early phase of healing process in open wounds in dogs. Acta Vet Brno 2003; 72: 273-277. [CrossRef]

25. Irkorucu O, Tascilar O, Cakmak GK, Karakaya K, Emre AU, Ucan BH, et al. The effect of sildenafil on an animal model for ischemic colitis. Dig Dis Sci 2008; 53: 1618-1623. [CrossRef]

26. Salcido RS. Viagra and wound healing: the NO connection. Adv Skin Wound Care 2008; 21: 106, 108-109. [CrossRef]

27. Yardimci S, Bostanci EB, Ozer I, Dalgic T, Surmelioglu A, Aydog G, et al. Sildenafil accelerates liver regeneration after partial hepatectomy in rats. Transplant Proc 2012; 44: 1747-1750. [CrossRef]

28. Colle I, De Vriese AS, Van Vlierberghe H, Lameire NH, DeVos M. Systemic and splanchnic haemodynamic effects of sildenafil in an in vivo animal model of cirrhosis support for a risk in cirrhotic patients. Liver Int 2004; 24: 63-68. [CrossRef]

29. Yuksel BC, Tanriverdi P, Ozel H, Avsar FM, Topaloglu S, Iskit AB. The effects of nitric oxide synthase blockers on mesenteric blood flow with bile duct ligation. Hepatogastroenterology 2003; 50 Suppl 2: ccxix-ccxxi.

30. Li J, Fu P, Deleon M, French BA, French SW. The effect of Viagra (sildenafil citrate) on liver injury caused by chronic ethanol intragastric feeding in rats. Exp Mol Pathol 2005; 78: 101-108. [CrossRef]

31. Eweka AO, Eweka A. The effects of sildenafil citrate on the liver and kidneys of adult wistar rats (Rattus norvegicus)-a histological study. In: Azita G, ed. sexual dysfunctions - special issues 2011;59-65.

32. Nna VU, Akpan UP, Okon VE, Atangwh o IJ. Hepatotoxicity following separate administration of two phosphodiesterase- 5 inhibitors (sildenafil \& tadalafil) and opioid (tramadol); evaluation of possible reversal following their withdrawal. J App Pharm Sci 2015; 5: 105-113. [CrossRef]

33. Jarrar BM, Almansour MI. Hepatic histological alterations and biochemical changes induced by sildenafil overdoses. Pak J Pharm Sci 2015; 28: 2119-2127.

34. Graziano S, Montana A, Zaami S, Rotolo MC, Minutillo A, Busardò FP, et al. Sildenafil-associated hepatoxicity: a review of the literature. Eur Rev Med Pharmacol Sci 2017; 21(1 Suppl): 17-22.

35. Pellegrini M, Rotolo MC, Busardò FP, Pacifici R, Pichini S. Nonallowed pharmacologically active substances in physical and sexual performance enhancing products. Curr Neuropharmacol 2017; 15: 724-730. [CrossRef]

36. Pichi ni S, Marchei E, Pacifi ci R, Marinelli E, Busardò FP. Chemsex intoxication involving sildenafil as an adulterant of GHB. Drug Test Anal 2017; 9: 956-959. [CrossRef]

37. Giorgetti R, Tagliabracci A, Schif ano F, Zaami S, Marinelli E, Busardò FP. When "chems" meet sex: a rising phenomenon called "ChemSex". Curr Neuropharmacol 2016; 15: 762-770. 